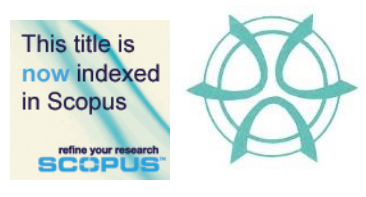

PLANNING MALAYSIA:

Journal of the Malaysian Institute of Planners

VOLUME 17 ISSUE 2 (2019), Page 146 - 157

\title{
THE NEED FOR THE IMPROVEMENT OF STREET VENDORS MANAGEMENT IN PUBLIC SPACES AT SURAKARTA CITY
}

\author{
Murtanti Jani Rahayu ${ }^{1}$, Imam Buchori ${ }^{2} \&$ Retno Widjajanti ${ }^{3}$ \\ ${ }^{1,2,3}$ Doctoral Program of Architecture and Urban Planning \\ UNIVERSITAS DIPONEGORO, SEMARANG, INDONESIA
}

\begin{abstract}
The presence of an activity in a public space should not obstruct the right of other users. In order to create an ideal public space as a shared space, the existence of various activities such as street vendors (SVs) must be properly managed. SVs, as well as other activities, should strengthen the function of public spaces and not the other way round. Stabilisation is implemented by regulating several characteristics of SVs location and activity as a form of SVs management in public spaces. This idea became the entry point for SVs improvement, although so far SVs conditions have not been optimally improved. Some new components/ indicators of arrangement will enrich the efforts for stabilisation. In this study, the analysis technique of partial least square (PLS), which negates a variety of assumptions was applied to test the effect of stabilisation on the change or improvement of SVs' welfare, behaviour, and location. The results show that the enrichment of components in stabilisation arrangement has a positive and significant effect on the three elements of SV improvement. The effect of stabilisation on SVs' behavioural changes had the highest value if compared to that of welfare and location changes.
\end{abstract}

Keywords: Stabilisation, public space, welfare, behaviour 
PLANNING MALAYSIA

Journal of the Malaysia Institute of Planners (2019)

\section{INTRODUCTION}

Surakarta city has long conducted SVs stabilisation at the governmental public spaces such as those located around pedestrians (without disturbing the right of pedestrians), city park, and open space. This step was taken by the government as a way of accommodating the needs and fulfilling the characteristics of SVs as well as keeping the beauty of the city. This further indicates that Surakarta city has made serious efforts in developing a good planning system that enhances city management and that equally conform to social justice and the beautification of the city which is sustainable (Hudalah, Winarso, \& Woltjer, 2010; Buchori, 2011). If the regulated stabilisation is not conducted, SVs will be regarded as a city element that is detrimental to the visual aesthetics of the environment, unexpected, and vulnerable to raise the conflict of space exploitation (Shirvani, 1985; Yatmo 2008). In addition, Yatmo (2008) calls that element out of place. In order to make SVs an element that contributes to the environment, its presence needs to be recognised and facilitated in the city development plan (McGee \& Yeung, 1977; Lefebvre, 1991; Yatmo, 2008). Accordingly, the state of ignored elements, out of place, or city pathology can ultimately change into an energetic city as the expected condition of SVs resulted from stabilisation in Surakarta City nowadays.

In Surakarta, stabilisation is undertaken by stipulating a location whose basis is a public space to be a legal retailing area for SVs through building some shelters, although the related retailing activities are still regarded informal (McGee \& Yeung, 1977; Kettles, 2007; Puspitasari, 2010; Tualeka, 2013; Schindler, 2014; Linares, 2018). According to Rahayu (2016), the success of arranging SVs in a public space will become one of the keys to successfully reduce poverty. While arrangements have been made, the increase in SV conditions has not occurred optimally. Therefore, some new arrangement components/ indicators are needed to enrich stabilisation efforts, in order to obtain optimum results.

The arrangement of SVs is one of the forms of interaction between humans and its surrounding environment (Rahayu, 2016). This interaction will lead to changes (Bintarto, 1989). These changes include welfare, location, and behavioural changes. Sunaryo (2004) also states that the physical condition of environment will really influence humans, either knowingly or unknowingly, so that it causes a change.

In the meantime, the objective of development per se is to achieve welfare (Bintarto, 1989). The constituent of welfare in the context of development can be defined as a change to a better or more qualified condition so that the change which is studied is the existing change of the welfare that aligns with the objectives of SVs arrangement.

Anchored in Koelle (1974), the indicator of welfare is seen from the quality of life which covers several aspects that entail income or material, 
Murtanti Jani Rahayu, Imam Buchori \& Retno Widjajanti

The Need for the Improvement of Street Vendors Management in Public Spaces at Surakarta City

physicality and health, mentality such as education, and spirituality pertinent to the sense that SVs arrangement is secured from both crimes and eviction.

A change of location refers to location displacement, which frequently leads to a condition whereby the SVs, in fact, will move their location again over the stated given position even after being officially arranged. In addition, with respect to the change of behaviour on the basis of Bloom's theory (Sunaryo, 2004), it can be split into three domains that comprise knowledge, attitude, and action. In accordance with Muhibbin Syah (2008), knowledge represents any information known by SVs so that they acquire adequate understanding through their five senses. Attitude refers to someone's efficacy playing a role in committing himself/herself to do something. Furthermore, action portrays the skills of psychomotor which manifest the acquired insights or knowledge and the mental attitude. The values consistently embedded in one's self will effectively control him/her. The behaviour in this context is in accordance with a change of behaviour towards the welfare experienced by SVs. This condition entails the improvement of insights or knowledge about welfare, the improvement of attitude towards welfare, and the improvement of action for the sake of welfare.

The existence of SVs can be identified through the characteristics of activities and locations (Mc Gee \& Yeung, 1977). Location characteristic, besides being related to the typical features of location, is also connected with the retailing regulation adjusted based on the condition of location (Rahayu, Werdiningtyas, \& Musyawaroh, 2016). The characteristic of activity is associated with a variety of activities which become the bases and are influenced by the location per se such as the types of goods, the types of trading facilities, the scale of consumer or customer service, capital, and income. There are two factors or characteristics which should be considered while conducting SVs stabilisation namely the characteristics of SVs location and SVs activity which can be intervened by the government (Werdiningtyas, Rahayu, \& Musyawaroh, 2012; Rahayu \& Musyawaroh, 2013; Rahayu et al., 2016). The aforementioned characteristics of stabilisation entail 21 components of arrangement, including the size of retail units $(\mathrm{P} 1)$, retail facilities $(\mathrm{P} 2)$, retailing activity time (P3), SVs grouping (P4), the strategic value of location (P5), accessibility (P6), retail supporting facilities (P7), parking area (P8), lighting (P9), clean water (P10), waste disposal facilities (P11), the aesthetics of location (P12), the distance to activities center (P13), the level of security (P14), the level of cleanliness/ hygiene (P15), the level of convenience (P16), education/ training from government (P17), legality (P18), agglomeration (P19), retribution (P20), and loan assistance from the government (P21) (Mc Gee \&Yeung, 1977; Regional Regulation 3/2008 Surakarta City; Donovan, 2008; Werdiningtyas et al., 2012; Novelia \& Sardjito, 2015; Rahayu et al., 2016; Widjajanti, 2016). Among the 21 components of stabilisation arrangement, there are 3 new components, namely retribution, the strategic value of location and the aesthetics of location 
PLANNING MALAYSIA

Journal of the Malaysia Institute of Planners (2019)

(Werdiningtyas et al., 2012; Rahayu et al., 2016; Hanifah \& Musadun, 2014). The new components will be tested for validity in influencing SVs changes, in addition to the 18 other arrangement components. Therefore, the enrichment of SVs stabilisation components that influence the changes in SVs can be obtained.

\section{METHOD}

The area of this study involved 25 locations of SVs stabilisation which were spread across Surakarta City, Central Java, Indonesia (Figure 1). This study used a quantitative method using the data collection technique SEM on the basis of Partial Least Square (PLS) that negates various assumptions as commonly made in the study on the basis of Ordinary Least Square (OLS) (Ghozali \& Latan, 2015).

The population of SVs engaged in this study was those retail units in Surakarta city that had been managed through stabilisation, both (a) those existing within the stated location of stabilisation and (b) those having moved over the given location of stabilisation. The tested hypothesis was the effect of stabilisation on welfare development, the change of location, and the improvement of the SVs' behaviours through evaluating (1) outer model with valuing convergent validity, discriminant validity, Cronbach's alpha, composite reliability and AVE, and (2) inner model with valuing $\mathrm{F}^{2}$ dan $\mathrm{R}^{2}$. This study uses the loading factor limit of 0.5 , cronbach's alpha of 0.7 , and the reliability composite value of 0.7 . Good results are indicated by numbers above the threshold.

The proportional random sampling technique was applied to get the number of respondents from the SVs that were still present at the location of stabilisation. The number of population was $551 \mathrm{SVs}$, with the degree of error $5 \%$ gained from 213 respondents. The number of population from the SVs that had moved over the location of stabilisation was difficult to be detected, so such SVs incorporated in this study were those who could be encountered by applying incidental/convenience sampling technique. They were $30 \mathrm{SVs}$ that represented them. The exogenous latent variable indicators of stabilisation arrangement include 21 components/indicators, consisting of 18 confirmatory components and 3 exploratory components (new components). In addition, the endogenous latent variables of change or improvement included the variables of welfare improvement (PI), behavioural change (BC) and location change (LC). The indicators of welfare improvement were comprised of income (PI1), health access (PI2), educational access (PI3), and security (PI4). Behavioural change entailed the insights appertaining to income (BC1), those associated with health access (BC2), those related to educational access (BC3), those corresponding to security (BC4), positive attitude towards the standard of income (BC5), positive attitude towards health access (BC6), positive attitude towards educational access, (BC7), positive attitude towards the importance of security (BC8), the efforts to achieve 
Murtanti Jani Rahayu, Imam Buchori \& Retno Widjajanti

The Need for the Improvement of Street Vendors Management in Public Spaces at Surakarta City

the standard of income (BC9), the efforts to get health access (BC10), the efforts to access education (BC11), and the efforts to be secured (BC12). The last endogenous latent variable was the location change (LC) at which some SVs had moved over the location of stabilisation, and some others still remained in the location. The stabilisation indicators were assessed using a rating scale 1-7, ranging from bad, moderate, to very good (Sugiyono, 2011). Likewise, the change or development indicators used a scale of 1-7 ranging from very decreasing, steady, to very high.

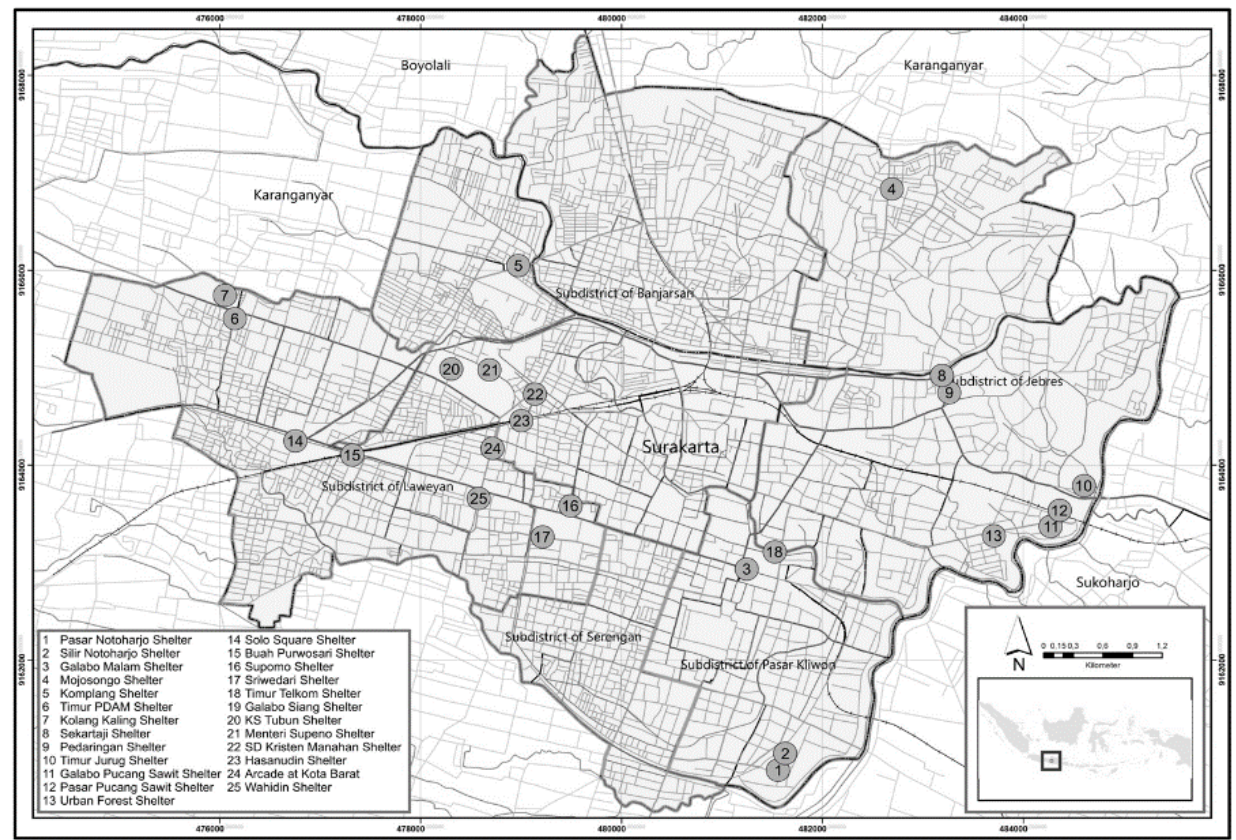

Figure 1 The map of the distribution of street vendor stabilisation locations in Surakarta Source: Observation results, 2017

\section{RESULTS AND DISCUSSION}

Anchored in the data of exogenous variable garnered from questionnaire, it could be discerned that the indicator or component of retribution determination was considered good by most of SVs as represented by $97 \%$ of SVs. The components of agglomeration, the level of cleanliness/ hygiene, accessibility, legality, the distance to activities center, the level of security, the strategic value of location, and the level of convenience were valued good by more than $60 \%$ of SVs. This condition indicates that these components of arrangement have been adequate in most of the locations, so that the locations are attractive, proximate, and reachable due to existing in a public space (Widyaningrum, 2009; Solomon-Ayeh, King, \& Decardi-Nelson, 2011; Onyango, Olima, \& Onyango, 2012; Bell \& Loukaitou, 
PLANNING MALAYSIA

Journal of the Malaysia Institute of Planners (2019)

2014, Widjajanti, 2016). Appertaining to legality component, the SVs had possessed a placement license as adequate proof in order that they could stay for retailing in an area of a public space whereby their activity status was informal. This condition is viewed by Bromley (2000) as the government ambiguous attitude since though their activities are categorized as informal; such condition is more profitable for the SVs.

For a couple of characteristics/variabels such as retailing activity time, SVs grouping, clean water, and retail facilities were valued good by less than $50 \%$ of SVs. It was due to these factors, that some other SVs assumed that those components were not yet optimal in their stabilisation area. Furthermore, a number of components such as the size of retail units, retail supporting facilities, education/training from government, aesthetics of location, lighting, parking area, and waste disposal facilities were only considered good by less than $50 \%$ of SVs. These components only sufficed in some locations. The last component was loan assistance from the government. Associated with this component, there were no any SVs who gave the value more than 4. Majority of SVs agreed that the government never allotted an amount of loan to them. In fact, in accordance with Tualeka (2013), loan is the most important thing for the SVs' business nowadays.

With regard to endogenous variable, the welfare improvement in this sense referred to an improvement that occurred after SVs were placed in the stabilisation area. The improvement of security became the first order in the welfare variable which was considered good by most of the SVs. The SVs security from eviction and crimes will lead to a state where the SVs are willing to follow the governmental management (Santos, 2017; Kettles, 2007; Rahayu \& Musyawaroh, 2013). SVs do not need to be afraid of either being chased by security forces while they are retailing, or being terrorised by crimes by virtue of staying in a crowded area.

The improvement of access to education took the second highest order to be valued good by the SVs; the improvement of access to health was placed in the third order by the SVs; and the last order was the improvement of income. This is in line with the point conveyed by Onyango et al. (2012) and Rahayu et al. (2016) in which after management, the income improvement is merely experienced by some SVs. According to behavioural change data, it was observed that an improvement mostly undergone by the SVs was at the indicator of action in accessing education and health as shown by more than $70 \%$ of SVs. Secondly, it was the action to gain income and to have security. The next most vital improvement was found at the SVs' attitude and insights or knowledge pertinent to the standard of education and health.

The fourth order of improvement happened to the indicators of attitude and insights or knowledge corresponding to the level of security which were experienced by 58\% of SVs. The last order for the experienced improvement by SVs was at the indicators of insights or knowledge and attitude towards the 
Murtanti Jani Rahayu, Imam Buchori \& Retno Widjajanti

The Need for the Improvement of Street Vendors Management in Public Spaces at Surakarta City

standard of income. Such attitude towards the standard of income meant to express the agreement towards the standard of income gained in every month. The assigned minimum income standard was the UMK of regency or city. These SVs knew and had agreed with the presence of UMK certified by the government in order that the societies could live prosperously. However, for them, the important thing was a real action and effort, not merely insights and attitude towards a governmental policy. More importantly, for them, they expected to have adequate profits from retailing everyday. Of what benefit is the use of knowing and agreeing if there was no real action to achieve it. In fact, the results obtained would only depend on how hard they tried, not on how much they knew and agreed. This is different from Muhibbin Syah (2008) in that between knowledge, attitudes and actions are interrelated. As for the location change, some stabilised SVs moved over to the stated location for various reasons. Some of them considered that the location they occupied was less strategic. This shows that the SVs retailing location is indeed very sensitive to changes or shifts even though they are only a few (Zees \& Sugiantoro, 2013). Some SVs assess the location of arrangement is not developed aesthetically, so it is less attractive for visitors to come (Rahayu, 2016).

The next step was data processing using the SmartPLS 3.0 program. Based on the result of the convergent validity test on outer models, it was found that there were 5 components that had a loading factor below 0.5 , namely: (P3) the retailing activity time, (P10) clean water, (P17) education/ training from government, (P20) retribution, and (P21) loan assistance from the government, so that those indicators must be removed from the model. As for the obtained AVE value, there were still found some variables that had a value of $<0.5$ so that the indicators that had the lowest loading factor values must be eliminated as well. They encompassed (P1) the size of retail units, (P8) parking area, and (P11) waste disposal facilities so that a good convergent validity was obtained with AVE> 0.5 . Furthermore, it can be seen that valid components/indicators that form the stabilisation arrangement and influence the changes in SVs are (P2) retail facilities, (P5) the strategic value of location, (P6) accessibility, (P7) retail supporting facilities, (P8) parking area, (P9) lighting, (P12) the aesthetics of location, (P13) the distance to activities center, (P14) the level of security, (P15) the level of cleanliness, (P16) the level of convenience, (P18) education/training from government and (P19) agglomeration. The 13 valid arrangement components consist of 11 old components and 2 new components.

Continuously, the reliability test was undertaken. Concerning the result of the reliability test, the Cronbach's alpha value of all constructs $>0.7$, and the composite reliability value $>0.7$, which meant that all constructs had fulfilled good construct reliability. The estimation result of PLS model can be seen in the following figure. 


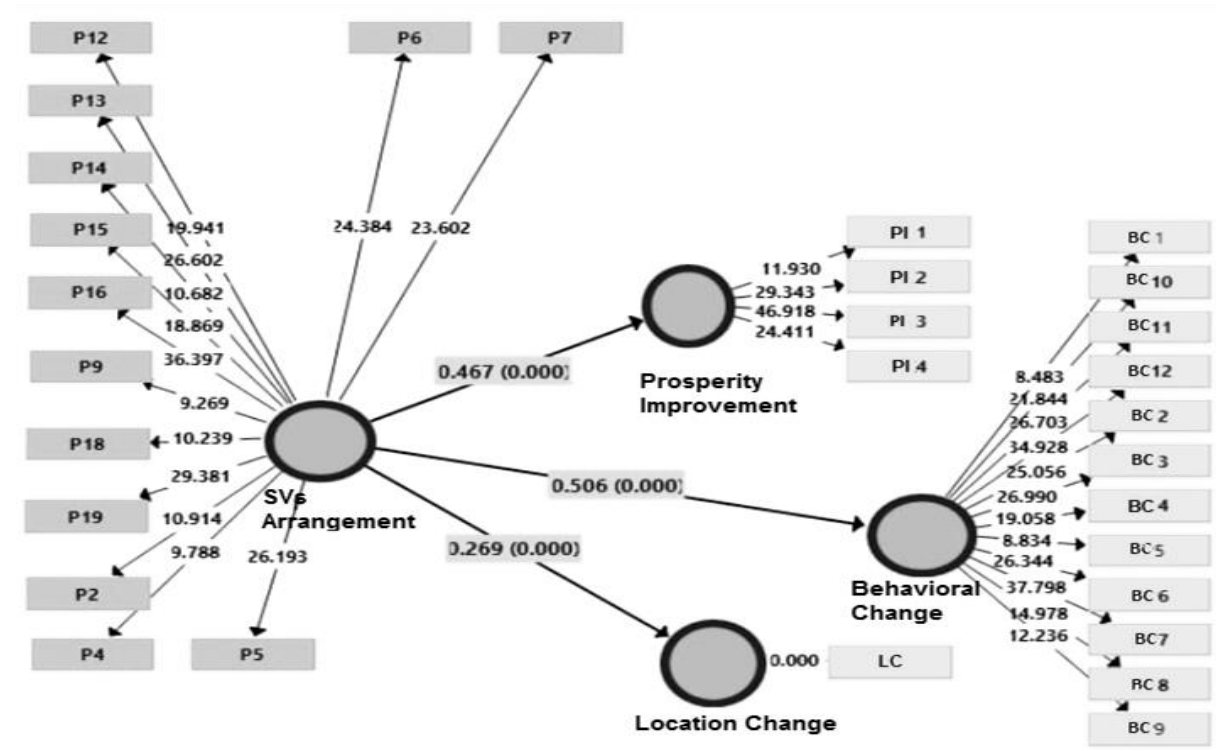

Figure 2 The estimation result of PLS model Source: Data processing, 2018

Based on the estimation result of the PLS (bootstrapping) model above, it can be explained that $\mathrm{p}$ value of the effect of SVs arrangement variable on changes in the SVs welfare is 0,000 , with a positive original sample of 0.467 . It can be concluded that SVs arrangement has a significant and positive effect on the improvement of SVs welfare as represented by 0.218 . This shows that the management objectives are achieved (Regional Regulation No. 3/2008, Surakarta City; Tualeka, 2013). The better implementation of stabilisation arrangements, the better effect on the welfare of SVs.

The $p$ value of the effect of SVs arrangement variable on SVs behavioural changes is 0,000 , with a positive original sample of 0.506 . It can be concluded that SVs arrangement has a positive and significant effect on the change or improvement of SVs' behaviours as indicated by 0.256 . The relationship between activities and the environment will directly be able to change humans' behaviour (Bintarto, 1989).

The $\mathrm{p}$ value of the effect of SVs arrangement variable on SVs location changes is 0,000 , with the original sample positive 0.269 . Hence, it can be concluded that SVs arrangement has a significant effect on SVs location changes as manifested by 0.072 . The conducted management will regulate where SVs should be. This is so that SVs can be a positive energy for the city and its people (McGee \& Yeung, 1977; Lefebvre, 1991; Yatmo, 2008). The results show that the better implementation of stabilisation arrangements, the better the behaviour of SVs and they feel more convenience in the arrangement location. 
Murtanti Jani Rahayu, Imam Buchori \& Retno Widjajanti

The Need for the Improvement of Street Vendors Management in Public Spaces at Surakarta City

The locations of SVs stabilisation which have been set by the government will make those locations legal for SVs even though their activities are still categorized as informal activities (Mc Gee \& Yeung, 1977; Kettles, 2007; Puspitasari, 2010; Tualeka, 2013; Schindler, 2014; Linares, 2018). This Surakarta governmental policy, other than to carry out the mandate of Law No. 26/2007 about spatial planning that has to accommodate the informal sectors within its spatial structure, is also in line with the basic problems of Surakarta city. Generally, the basic problems occurring in Surakarta city encompass three cases which entail spatial planning, poverty, and marginal people (Rahayu \& Musyawaroh, 2013). One of the problems faced by marginalised people is the presence of SVs.

Surakarta City, likewise in Singapore, arranges SVs in a number of public space locations which are determined by the government. This way, besides preventing slums and congestion, is also capable of attracting tourists (Rahayu \& Musyawaroh, 2013; Henderson, 2012). The SVs prefer such management in the form of stabilisation (Lince, 2011; Rahayu, 2016). One of the objectives of the SVs management or arrangement is to create welfare for SVs besides other goals for the sake of the orderliness and the aesthetics of the city. In addition, this finding also aligns with the results of studies conducted by Henderson (2012), and Rahayu and Musyawaroh (2013), whereby the management or arrangement of SVs will influence their income although not all of the SVs gain an improvement.

Besides affecting the increased SVs' income, the SVs management also encourages SVs to have an increased ability to access health and education. SVs themselves realize that becoming SVs is caused by low education and skills. Hence, for SVs, improving their education or their children's education is important in order that they can live more prosperously (Manning \& Pratomo, 2013). SVs also want better quality health for themselves and their families in order to continuously work hard and try better. SVs in this sense experience vertical mobility in the aspects of income, education, and health. This is the evolutionary condition as stated by Santos (2017).

After SVs are managed through stabilisation, they can carry out their business calmly and securely because the places where they trade do justice to the proper characteristics and are legal as well. This point becomes an entry for the stabilised SVs to improve their knowledge, attitude, and efforts for the sake of welfare. The increase of behaviours experienced by most of the SVs happen to the improvement of their actions in reaching welfare, the improvement of their knowledge, and lastly, the improvement of their attitude.

This condition indicates that after being managed or arranged, most of the SVs try harder to prosper. Their efforts to become more prosperous are manifested by the improvement of their behaviours in achieving welfare. The 
PLANNING MALAYSIA

quality of a good stabilisation management is articulated by the SVs through trying harder in doing business so that their welfare increases.

Given the fact that some stabilised SVs, later on, move over to the given stabilisation locations, it indicates that there is a sort of vulnerability from the locations of stabilisation that they occupy. SVs' habit of looking for a location merely based on their intuition but not in accordance with a particular rule (Onyango et al., 2012) eventually leads them to feel that the locations of stabilisation which they occupy are less appropriate based on their perceptions as regards the proper locations they expect. According to the SVs who have moved over to the given stabilised locations, even though their income is mostly increased after getting managed, the welfare has not completely increased in overall. The increment of their income has not yet been in line with the increasing number of their needs. The SVs move over to the designated locations of stabilisation because they expect to gain a significant increase of welfare.

\section{CONCLUSION}

Of the 21 stabilisation components/indicators, there are 13 components that are valid in determining the good or bad effect of the SVs arrangement. Within the 13 components, 2 of them are new components/exploratory, namely the strategic value of location and the aesthetics of location. This research has shown the enrichment of components in stabilisation arrangements that affect changes in SVs. Overall, those components encompass retail facilities, SVs grouping, the strategic value of location, accessibility, retail supporting facilities, lighting, the aesthetics of location, the distance to activities center, the level of security, cleanliness/ hygiene, the level of convenience, legality, and agglomeration. The 8 indicators which are not valid in determining the good or bad effect of SVs arrangement are the size of retail units, the retailing activity time, parking area, clean water, waste disposal facilities, education/ training from government, retribution, and loan assistance from the government.

Stabilisation variables have a significant and positive effect on the change or improvement variables, although in the weak category. The better the condition of the components in stabilisation arrangements will lead to better changes in SVs. The order of the effect of the magnitude of stabilisation, which is the most occurrence in behavioural changes, then the changes in welfare, and finally the changes in location. 
Murtanti Jani Rahayu, Imam Buchori \& Retno Widjajanti

The Need for the Improvement of Street Vendors Management in Public Spaces at Surakarta City

\section{ACKNOWLEDGMENT}

Our utmost gratitude goes to Indonesia Endowment Fund for Education, Universitas Diponegoro, and Universitas Sebelas Maret for their various support in conducting this study. Most importantly, our gratitude goes to Rr. Ratri W and all friends who are too many to be mentioned here individually. Hopefully, this article will be beneficial to both science and the society at large.

\section{REFERENCES}

Bell, J. S., \& Loukaitou-Sideris, A. (2014). Sidewalk informality: An examination of street vending regulation in China. International Planning Studies, 19, 221-243.

Bintarto. (1989). Interaksi desa-kota dan permasalahannya. Jakarta: Ghalia Indonesia.

Bromley, R. (2000). Street vending and public policy: A global review. International Journal of Sociology and Social Policy, 20(1/2), 1-28.

Buchori, I. (2011). Konsep sistem informasi rencana tata ruang wilayah untuk kabupaten/kota di Indonesia. Jurnal Tata Loka, 13(4), 224-234.

Donovan, M. (2008). Informal cities and the contestation of public space: The case of Bogotá's street vendors. Urban Study, 45(1), 29-51.

Ghozali, I., \& Latan, H. (2015). Partial least squares: Konsep, teknik dan aplikasi menggunakan Smart PLS 3.0 (Edisi 2). Semarang: Badan Penerbit Undip.

Hanifah, U., \& Mussadun. (2014). Penilaian tingkat keberhasilan relokasi PKL di kawasan Pasar Waru dan Simpang Lima. Jurnal Perencanaan Wilayah dan Kota SAPPK ITB dan IAP, 25(3), 228-242.

Henderson, J. C. (2012). Hawker centers as tourist attractions: The case of Singapore. International Journal of Hospitality Management, 849-855.

Hudalah, D., Winarso, H., \& Woltjer, J. (2010). Planning by opportunity: An analysis of periurban environmental conflict in Indonesia. Environment and Planning A, 42(9), 2254-2269.

Kettles, G. W. (2007). Legal responses to sidewalk vending: The case of Los Angeles, California. In J. Cross \& A. Morales (Eds), Street entrepreneurs people, place, and politics in local and global perspective (pp. 58-78). New York: Routledge.

Koelle, H. (1974). An experimental study on the determination of a definition for the quality of life. Regional Studies, 8, 1-10.

Lefebvre, H. (1974). The production of space, translated by (1991), , . (N.-S. Donald, Trans.). Oxford, UK and Cambridge, Mass, USA: Blackwell.

Linares, L. A. (2018). The paradoxes of informalizing street trade in the Latin American city. International Journal of Sociology and Social Policy, 38(7-8), 651-672.

Lince, S. (2011). The informal sector in Jinja. African Studies Review, 54(2), 73-93.

Manning, C., \& Pratomo, D. S. (2013). Do migrants get stuck in the informal sector? Findings from a household survey in four Indonesian cities. Bulletin of Indonesian Economic Studies, 49(2), 167-192.

McGee, T. G., \& Yeung, Y. (1977). Hawkers in Southeast Asian cities: Planning for the bazaar economy. Ottawa: International Development Research Centre.

Muhibbin Syah, M. (2008). Psikologi pendidikan. Bandung: PT Remaja Rosda Karya.

Novelia, A. S., \& Sardjito. (2015). Kriteria penentuan lokasi pedagang kaki lima berdasarkan preferensi pedagangnya di kawasan perkotaan Sidoarjo. Jurnal Teknik ITS, 4(1), 230. 
Onyango, J., Olima, W., \& Onyango, L. (2012). Dynamics of street vending phenomenon in the Kisumu Municipality, Kenya. International Journal of Arts and Commerce, 1(4), 107-120.

Puspitasari. (2010). Penataan PKL kuliner untuk mewujudkan fungsi tata ruang kota di ruang kota di Kota Yogyakarta dan Kabupaten Sleman. Jurnal Mimbar Hukum, 22(3), 588-606.

Rahayu, M. J., \& Musyawaroh. (2013). Stabilisasi sebagai bentuk penataan PKL makanan siap saji di Kota Surakarta. Jurnal Tata Loka, 15(1), 39-52.

Rahayu, M. J., Werdiningtyas, R., \& Musyawaroh. (2016). Faktor-faktor yang mempengaruhi keberhasilan penataan PKL sebagai strategi penataan ruang Kota Surakarta. Region, 6(3), 109-122.

Rahayu, M. J. (2016). Perubahan kondisi PKL pasca penataan stabilisasi dan relokasi di Kota Surakarta. In G. Hardiman (Ed.), Sustainable architecture and urbanism (pp. 43-59). Semarang: Departemen Arsitektur Fakultas Teknik Universitas Diponegoro.

Santos, M. (2017). The shared space: The two circuits of the urban economy in underdevelopment countries. London and New York: Methuen.

Schindler, S. (2014). Producing and contesting the formal/informal divide: Regulating street hawking in Delhi, India. Urban Studies, 51(12), 2596-2612.

Shirvani, H. (1985). The urban design process. New York: Van Nostran Reinhold Company.

Solomon-Ayeh, B. E., King, R. S., \& Decardi-Nelson, I. (2011). Street vending and the use of urban public space in Kumasi, Ghana. The Ghana Surveyor, 4(1), 20-31.

Sugiyono. (2011). Metode Penelitian Kuantitatif, Kualitatif dan R\&D. Bandung: Alfabeta.

Sunaryo. (2004). Psikologi untuk keperawatan kedokteran. Jakarta: EGC.

Tualeka, B. A. (2013). Memahami kebijakan pembinaan PKL Surabaya, kajian terhadap perda Kota Surabaya No.17 Tahun 2003. DIA Jurnal Administrasi Publik, 11(1), 149-159.

Werdiningtyas, R., Rahayu, M. J., \& Musyawaroh. (2012). Hawkers behaviour and characteristic as an important factor to empower local economy. 2nd CONVEEESH \& 13th SENVAR, 2, 1-10. Yogyakarta: Duta Wacana Christian University.

Widjajanti, R. (2016). The space utilization by street vendors based on the location characteristics in the education area of Tembalang, Semarang. Procedia - Social and Behavioral Sciences, 227, 186-193.

Widyaningrum, R. (2009). Karakteristik aktivitas pedagang kaki lima pada kawasan komersial di pusat kota (Studi kasus: Simpang Lima Semarang). Jurnal Teknik, 20(3), 162-170.

Yatmo, Y. A. (2008). Street vendors as 'out of place' urban elements. Journal of Urban Design, 13(3), 387-402.

Zees, E. A. T. \& Sugiantoro. (2013). Sensitifitas pedagang kaki lima terhadap lokasi pada skala mikro di Kota Manado. Jurnal Perencanaan Wilayah dan Kota ITB SAPPK, 2(3), 777-797

Received: $25^{\text {th }}$ January 2019. Accepted: $2^{\text {nd }}$ July 2019. 